\title{
Türkiye'ye Yönelik Dış Turizm Potansiyelinin Panel Çekim Modeli İle Analizi
}

Analysis of Turkey's Foreign Tourism Potential with Panel Gravity Model

\author{
Buket BULUK*, Erol DURAN** \\ *Arş. Gör., Çanakkale Onsekiz Mart Üniversitesi, Terzioğlu Yerleşkesi, Turizm Fakültesi, 17100, Merkez, Çanakkale. \\ E-posta: bulukbuket@comu.edu.tr \\ ORCID: 0000-0001-5646-6166 \\ **Doç. Dr., Çanakkale Onsekiz Mart Üniversitesi, Terzioğlu Yerleşkesi, Turizm Fakültesi, 17100, Merkez, Çanakkale. \\ E-posta: eroldurantr@yahoo.com \\ ORCID: 0000-0003-0116-3189
}

MAKALE BILGILERI

Makale işlem bilgileri:

Gönderilme tarihi: 9 Kasım 2017

Düzeltme: 5 Mart 2018

Kabul: 8 Mart 2018

Anahtar sözcükler: Panel Çekim

Modeli, Dış turizm potansiyeli,

Türkiye.

ARTICLE INFO

Article history:

Submitted: 9 November 2017

Resubmitted: 5 March 2018

Accepted: 8 March 2018

Key words: Panel Gravity Model, Foreign tourism potential, Turkey.

\section{ÖZ}

Bu araştırmada, 2016 yılında Türkiye'yi ziyaret eden turistlerden elde edilen yatay kesit verileri kullanılarak panel çekim modeli aracılığıyla Türkiye'nin dıș turizm potansiyelini tespit etmek ve bu potansiyeli mevcut turizm pazarları dıșındaki farklı pazarlar için de geliștirmek amaçlanmıștır. Çalıșma sonucunda, Türkiye'yi ziyaret eden turist sayısının, gelinen ülkenin ekonomik gelişmişliği faktöründen olumlu, ülkenin uzaklığı faktöründen ise olumsuz yönde etkilendiği tespit edilmiștir. Turistlerin geldikleri ülkenin nüfus açısından büyük olması faktörünün ise turist akımı üzerinde bir etkisinin bulunmadığı saptanmıștır. Ayrıca, turistlerin geldikleri ülkenin Türkiye ile birtakım bağlarının (tarihi, kültürel, etnik) veya ortak sınıra sahip olması faktörünün turist rakamları üzerinde artırıcı, ülkenin bir Müslüman ülkesi olması faktörünün ise gelen turist rakamlarını azaltıcı bir etkide bulunduğu görülmüștür. Araștırma, Türkiye'yi belirli ülkelerin ziyaret ettiği ve belirli turizm aktivitelerinin gerçekleștirildiği ülke imajından kurtarabilmesi, Türkiye'nin turist akımını etkileyen faktörleri belirlemesi ve bu doğrultuda da Türkiye'nin dış turizm potansiyelinin tespit edilmesi bağlamında önem taşımaktadır.

\section{ABSTRACT}

This research aims to determine the foreign tourism potential of Turkey to develop different markets outside of existing tourism markets by using the panel gravity model and the cross-sectional data obtained from the tourists who visited Turkey in 2016. As a result of the study, it was determined that the number of tourists visiting Turkey is affected positively by the economic development factor and negatively by the distance factor of the country of origin. It was also determined the original country's -where tourists come from- big population has any effect on tourists' flow. In addition, it was seen that the factor of having an affiliation with Turkey (historical, cultural, ethnical) or having a common border has an increasing effect on tourist flow, although the factor of being a Muslim country has a decreasing effect on tourist flow. The research is important in terms of changing Turkey's image as a country visited by certain countries and carried out by certain tourism activities. It is also important in terms of determining the factors that affect Turkey's tourist flow and determining the foreign tourism potential of Turkey in this direction.

\section{GíRiş}

Turizm sektörü, dünyada en hızlı büyüyen ve gelişen sektörlerin arasında yer almaktadır. Buna paralel olarak, global anlamda turist sayısı ve turizmden sağlanan gelir de sürekli olarak yükselmektedir. 1950'li yıllarda uluslararası turizme katılan turist sayısı 25 milyon iken bu rakam günümüzde 1 milyar 235 milyona ulaşmıştır (Göğebakan 2015). Turizm sektörü, hem uluslararası turizm hareketleri hem de uluslararası turizm gelirlerinde yıllık olarak \%4-4,5 oranında bir artışa sahiptir ve bu artışın devam etmesi beklenmektedir. Bu kapsamda, Dünya Turizm Örgütü'nün istatistiklerine göre, dünya turizmi adına yaşanan tüm olumsuzluklara rağmen, uluslararası turist rakamları 2015 yılında 2014'e kıyasla \%4,4 oranında artışla 1,184 milyon olarak gerçekleşmiştir (UNWTO 2016). 2020 yılında ise uluslararası 
turist sayısının 1,6 milyarı ve uluslararası turizm gelirlerinin 2 milyar doları geçmesi beklenmektedir (Pırnar 2013).

Konu ile ilgili yapılan çalışmaların sonuçlarının da desteklediği gibi turizmin ekonomik büyüme, istihdam ve kalkınma konuları üzerindeki etkileri sebebiyle önemi artmaktadır (Bahar 2006). Turizm sektörü, Gayri Safi Yurtiçi Hasıla (GSYH) ile birçok ülke istihdamının önemli bir bölümünü karşılamaktadır. Bununla birlikte turizm

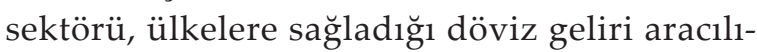
ğıyla, bütçe açılıklarının giderilmesi noktasında büyük bir katkı sağlamaktadır (Özcan 2015). $\mathrm{Bu}$ özelliğiyle turizm, vergi gelirlerinin artırılmasında ve ödemeler dengesindeki sorunların giderilmesinde önemli bir etkendir. Otomasyon ve mekanizasyon olanaklarının sınırlı olduğu turizm sektöründe, yatırım-istihdam oranlarının da genellikle yüksek olduğu bilinmektedir. Turizm, sahip olduğu uyarıcı etkisiyle beraber diğer ulaşım, yiyecek-içecek, tarım, iletişim, inşaat vb. sektörlerde de istihdam ve gelir düzeylerini artırmaktadır (Usta 1995: 98).

Dünya Seyahat ve Turizm Konseyi ile Oxford Economics'in yapmış oldukları "Turizm Sektörünün Yıllık Ekonomik Katkısı" araştırmasının sonuçları, turizm sektörünün, dünya ekonomisi bağlamında önemli bir yere sahip olduğunu göstermiştir. Turizm sektörü, 2014 yılı içindeki turizm faaliyetleri sonucunda dünya ekonomisine $\% 3,58$ oranında katkı, dünya toplam GSYH'sine ise 2,2 trilyon dolar ve 105 milyon istihdam olanağ1 yaratan bir sektör konumuna yükselmiştir (Şit 2016). Ayrıca, turizm endüstrisinin ulaşım, konaklama, yiyecek-içecek gibi diğer endüstrilere yapmış olduğu dolaylı ve doğrudan etkiler de ele alındığında, dünya toplam GSH'sine $\% 3$ oranında katkıda bulunduğu görülmüştür. Bugün hala, dünya genelindeki her 11 istihdamdan 1'ine sahip olan turizm sektörü, aynı zamanda dünya toplam GSH'sinin \%9,5 oranina sahip, dünya toplam yatırımlarının $\% 4,4$ 'ünü karşılayan ve dünya toplam ihracatının ise $\% 5,4^{\prime}$ ünü elinde bulunduran bir sektördür. 2014 yılı dünya turizmi verilerinin değerlendirmeleri sonucunda turizm sektörü, dünyada turizm sektörü içinde istihdam ettiği kişi sayısını 1,4 milyon artırarak toplamda
4,7 milyon yeni iş olanağ 1 yaratmıştır. Bu sonuç, dünya toplam istihdam rakamları üzerinde turizm sektörünün katkısını $\% 1,8$ yükseltmiştir.

Turizm ve ekonomik büyüme ilişkisi ile ilgili yapılan alanyazın taraması sonucunda, birçok yerli ve yabancı çalışmaya ulaşılmıştır. Balaguer ve Cantavella-Jordá (2002), İspanya'nın uzun dönem ekonomik kalkınmasında turizmin rolünü araştırdığı çalışmasının sonucunda, turizmin İspanya'nın ekonomik büyümesi üzerinde olumlu yönde katkısının bulunduğunu tespit etmiştir. Araştırmacılar, çalışma sonuçlarından hareketle, İspanya'nın son 30 yıl içindeki ekonomik büyümesinin, uluslararası turizmin sürekli artmasına bağlı olduğuna işaret ettiğini belirtmişlerdir. İspanya'nın ekonomik büyümesinde turizmin etkisini inceleyen bir diğer çalışma da, Jiménez ve Ortuño'nun (2005) çalışmalarıdır. Jiménez ve Ortuño (2005), 1960'lardan 2002 yılına kadar olan dönemde turizmden elde edilen döviz gelirlerinin, imalat sanayi ürünlerinin ithalatı üzerindeki rolünü incelemiştir. Çalışma sonucunda, imalat sanayi ürünlerinin ithalatı ile turizm gelirleri arasında uzun dönemli bir ilişkinin varlığ́nın bulunduğu görülmüştür. Katırcıoğlu (2009) Kıbrıs için yaptığ ${ }_{1}$ çalışmasında; turizm, uluslararası ticaret ve ekonomik büyüme arasındaki ilişkiyi araştırmıştır. Araştırma sonucunda, söz konusu değişkenler arasında uzun dönemli bir ilişkinin olduğunu tespit etmiştir. Ayrıca, ekonomik büyümenin, uluslararası ticareti geliştirdiği ve Kıbrıs'a turist gelmesini teşvik ettiği yönünde bulgulara ulaşmıştır. Katırcıoğlu'nun (2010) yine Kıbrıs'ı ele aldığı ve GSYİH, gelen turist sayısı, üniversitelerde okuyan öğrenci sayısı ve reel döviz kuru değişkenleri arasındaki ilişkiyi Granger nedensellik testi ile incelediği çalışmasında; büyüme ile uluslararası turizm ve yüksek öğretim değişkenleri arasında uzun dönemli bir ilişkinin olduğu görülmüştür.

Küresel ekonomide önemli bir noktada bulunan turizm sektörü, Türkiye ekonomisi içinde de son derece önemli bir konumdadır. Dünyanın önde gelen turizm destinasyonlarından biri olan Türkiye'de turizm, ülke ekonomisi içinde döviz geliri sağlaması nedeniyle önem arz eden bir sektördür. TURSAB'ın (2016) verileri değer- 
lendirildiğinde, 2013 yılı itibariyle Türkiye'nin turizmden elde ettiği gelirin, GSYH'sinin $\% 3,9^{\prime} u$ oranında olduğu görülmüştür. Ancak Türkiye, 2013 'te dünyada en fazla turist ağırlayan ilk on ülkenin arasında yer almasına ve turizm aracilı$\breve{g}$ gyla sağladığ $\breve{1}_{32,3}$ milyar dolar gelire rağmen, dünyada turizmden en fazla gelir elde eden ilk on ülke sıralamasına girememiştir (UNWTO 2016). Bu durum, Türkiye'nin turizmde izlediği fiyat ve pazarlama politikalarından kaynaklanmaktadır. Oysa Türkiye'nin de içinde yer aldığ Akdeniz çanağındaki bir ülke konumunda bulunan İspanya, 2013 yılında 65,2 milyar dolar turizm gelirine sahipken, Fransa'nın turizm geliri 55,4 milyar dolar, İtalya' nın turizm geliri ise 45,5 milyar dolardır (UNWTO 2015). Bu rakamlar, Türkiye'nin küresel turizm potansiyelinin tespit edilmesi gerektiğinin ve bu potansiyele uygun politikaların izlenmesinin, sektörün daha planlı bir biçimde geliştirilmesi bağlamında önem teşkil ettiğini göstermektedir. Bu durum öncelikle Türkiye'nin tek başına deniz-kum-güneş ülkesi olarak algılanmasının önlenmesi ve bu amaçla alternatif turizm politikaları oluşturularak Türkiye'nin hedef pazarının çeşitlendirilmesi ve turizm pastasından daha fazla pay alabilmek için yeni politika ve planlamaların belirlenmesiyle mümkün olabilecektir.

Yukarıda da belirtildiği üzere, turizm ve ekonomik büyüme ilişkisi üzerine yapılan alanyazın taraması sonucunda, Türkiye için de yapılmış birçok çalışmanın olduğu görülmüştür. Kırbaş ve Kasman (2004), Türkiye'nin 1963-2002 dönemini Granger nedenselik analizi yöntemiyle inceledikleri çalışmalarında, turizm gelirlerinden ekonomik büyümeye doğru tek yönlü bir ilişkinin olduğunu tespit etmişlerdir. Söz konusu tespit ile araştırmacılar, turizmin Türkiye'nin ekonomik büyümesine olumlu yönde bir katkı sağladığını belirtmişlerdir. Bu çalışmanın sonuçları ile benzerlik gösteren bir başka çalışma da Gündüz ve Hatemi-J'e (2005) aittir. Gündüz ve Hatemi-J (2005) gelen turist sayısı, GSYH ve reel döviz kuru değişkenlerini kullanarak, turizm ve ekonomik büyüme arasındaki ilişkiyi, Bootstrap nedensellik analizi aracıllı̆̆ıla incelemişlerdir. Çalışmanın sonucunda, artan turist sayısının ekonomik büyümeyi canlandırdığı so- nucuna ulaşmışlardır. Yıldırım ve Öcal'ın (2004) Türkiye için yapmış oldukları çalışmalarında ise turizm ile ekonomik büyüme arasında uzun dönemli bir ilişkinin bulunduğu ve bu ilişki doğrultusunda turizm gelirlerinin ekonomik büyümeyi olumlu yönde etkilediği sonucu ortaya çıkmıştır. Bahar (2006), 1963-2004 dönemi turizm gelirlerini ve GSYH'sini VAR modelini kullanarak incelediği çalışmasında, turizmin ekonomik büyüme üzerinde olumlu bir etki yarattığını ve turizm ve ekonomik büyüme arasında uzun dönemli ve karşılıklı bir ilişkinin bulunduğunu tespit etmiştir. Kızılgöl ve Erbaykal (2008), Türkiye'deki turizm gelirleri ile ekonomik büyüme arasındaki nedensellik ilişkisini, Toda-Yamamoto yöntemi çerçevesinde incelemişlerdir. 1992:01-2006:02 dönemlerini kapsayan üçer aylık veriler kullanılarak yapılan test sonuçlarına göre, ekonomik büyümeden turizm gelirlerine doğru tek yönlü bir nedensellik ilişkisi ortaya çıkmıştır. Bu sonuca göre, Türkiye'nin daha fazla turizm geliri elde etmek için sürdürülebilir bir ekonomik büyüme sağlaması gerektiği söylenebilir.

Türkiye'nin dış turizm potansiyelini tespit etmeyi amaçlayan bu araştırmada, ülkemiz turiz-

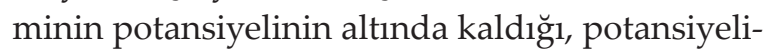
ne ulaştığ lenmeye çalışılacaktır. Bu bağlamda, gelen turist sayısının potansiyelin altında kaldığ 1 ülkelerdeki turist akımının geliştirilebilmesi amacıyla, hedefe yönelik tanıtım ve teşvik politikalarının da aracı olarak kullanılması sonucunda iki taraflı politikalar belirlenerek ilişkiler geliştirilebilecektir. Böylece Türkiye turizmi, daha önce girmediği ancak potansiyelinin bulunduğu farklı turizm pazarlarına girebilecek ve ülkemiz ana pazarlarının çeşitli sebeplerle çekilmesi durumunda yaşanabilecek ekonomik krizlerin daha az zararla karşılaması sağlanacaktır.

\section{TÜRKIYE'NIN TURIZM POTANSIYELI}

Turizm sektörü, özellikle son yıllarda kaydedilen gelişmelerle birlikte Türkiye' nin 'yükselen yeni sektörü' konumundadır. Türkiye turizminin büyümesine katkıda bulunmak amacıyla 1923 yılında kurulan ve bugünkü adıyla Türkiye Turing ve Otomobil Kurumu olarak bilinen kurum, tarihi 
eserlerin onarılarak hizmete sunulmasında Türkiye turizmine önemli katkılar sağlamıştır (Dalman 2016). Özellikle 1985 'ten sonra dişa açılma ve liberalleşme politikaları doğrultusunda devlet tarafından turizm yatırımlarının artırılmasına yönelik politikalar, turizm sektörüne sağlanan krediler, ulaşım olanaklarının iyileştirilmesi ve tanıtım faaliyetleri doğrultusunda Türkiye'yi ziyaret eden turist rakamlarında ve gelir miktarında büyük artışlar kaydedilmiştir. Devletin sağlamış olduğu bu destekleyici uygulamalar sonucunda, 1980'de GSYH'den \%0,6 oranında pay alan turizm, 2015 'te $\% 6,2$ oranında paya sahip olmuştur (TURSAB 2016).

Turizmin gelişmesi; Türkiye'ye giren döviz miktarında, ödemeler dengesi açığını kapatmada, istihdam oranının ve ulusal gelirin artışında, alt yapı olanaklarının, bankacılık ve ticaret faaliyetlerinin gelişmesinde, ulaşım, yiyecek-içecek ve hediyelik eşya gibi birçok sektörün büyümesinde önemli bir etkendir (Kızılgöl ve Erbaykal 2008; Özer 2015). Günümüzde turizm sektörü ülkemize, imalat sanayisinden sonra en fazla döviz ve istihdam kaynağ numunda yerini almaktadır. Ancak, Türkiye'nin de dahil olduğu Ortadoğu ülkeleri için çeşitli nedenlerle iyi geçmeyen 2015 yıll, turizm sektörü açısından da son yılların en kötü sonuçlarını doğurmuştur. Rusya'da 2014'ün son çeyreğinde başlayan ekonomik krizin olumsuz etkilerinin yaşandığ 1 sektörde, bu ülke pazarında 850 bin kişiye yakın azalma görülmüştür. 2015'te Rusya ile yaşadığı uçak krizi sonrasında Türkiye'nin turizm geliri, 2014 yılına kıyasla \%8,3 düşüş yaşayarak 31 milyar 464 milyon 777 bin dolara gerilemiştir (Nayır 2016). Aynı şekilde İstanbul Sultanahmet'te 12 Ocak 2016' da gerçekleşen ve Alman turist kafilesinin hedef alındığ 1 bombalı saldırıdan sonra yılın ilk dört ayında bir önceki yıla oranla \%35,43'lük düşüş yaşanmıştır (Coşan 2016).

Öte yandan, Türkiye'nin de içinde bulunduğu Orta Doğu ülkelerinde yaşanan terör olayları ve bu olaylar doğrultusunda ortaya çıkan güvenlik açığı da Türkiye'nin son iki yıl içindeki turizm potansiyelini rakamsal ve oransal olarak bir hayli geriletmiştir (Çardak 2016). Bu durum, özellikle
Türkiye gibi turizm faaliyetlerini belirli pazarlara ve belirli turizm türlerine bağımlı bir şekilde gerçekleştiren ülkeler adına daha ağır ekonomik sonuçlara yol açabilmektedir. Bu ve benzeri durumların yaratacağı olumsuz sonuçlardan korunmak için ise Türkiye'nin turizm potansiyelinin iyi değerlendirilmesi, turizm politikalarının gözden geçirilmesi ve yeni pazarlama stratejilerinin harekete geçirilmesi gerekmektedir.

\section{TÜRKIYE'NIN TURIZM FAALIYETLERI}

Üç tarafı denizlerle çevrili olması ve kıyı bölgesinde yer alan illerde güneşli gün sayısının fazla olması sebebiyle Türkiye turizminde deniz turizminin deniz-güneş-kum üçlüsüne dayalı boyutu ilk sırada yer almaktadır (Çetin ve Gürgil 2014). Güney Ege'de İzmir, Ayvalık, Çeşme, Kuşadas1, Datça, Bodrum, Bozburun, Marmaris, Göcek, Fethiye kıyıları mevcut iken Akdeniz'de Kemer, Kaş, Finike, Kalkan, Antalya, Alanya ve Mersin, Türkiye'nin başlıca kıyılarındandır. Karadeniz'de ise Samsun, Yakakent, Terme, Ordu, Yason Burnu, Giresun ve Kastamonu, deniz turizminin gelişmiş olduğu kıyılar açısından zengindir. Ancak, Ege ve Akdeniz bölgesinde yer alan kıyıların güneşli gün sayısının uzunluğu, Karadeniz kıyılarına göre oldukça yüksektir. Karadeniz, turizm sektöründe deniz-kum-güneş turizmi ile sınırlı ölçüde yer almakta iken yüksek noktalarında ise yayla turizmi ile öne çımaktadır (Yüksel 2013).

Deniz turizmine ek olarak Side, Köyceğiz, Kuşadası ve Kapadokya Turizm Gelişim Projeleri ile turizm hizmet ve ürünlerinin çeşitlendirilmesine dayalı alternatif turizm faaliyetlerinin geliştirilmesine yönelik adımlar atılmıştır. Bu kapsamda golf turizmi, kongre turizmi, kültürel miras turizmi, futbol turizmi, kruvaziyer ve yat turizmi, ekoturizm ve rafting gibi turizm türlerinin gelişimine yönelik adımlar atılmıştır.

Gerek coğrafi konumu gerekse jeopolitik özellikleri ile Türkiye, dünyanın en önemli tarihi ve kültürel değerlerine ev sahipliği yapmaktadır. İçerisinde barındırdığı değişik kültürleri ve yaşam biçimleri, farklı ırk ve inanışlara sahip insanları, yeraltı ve yerüstü zenginlikleri ve otantik değerleri, Türkiye'yi adeta zengin bir mozaiğe sahip ülke konumuna taşımaktadır (Kaynar 2009). 
Bu zengin mozaik, Türkiye turizmi bağlamında çok önemli bir arz kaynağını ve rekabeti mümkün olmayan bir avantajı ifade etmektedir. Tarihi ipek yolu güzergâhında da yer alan Türkiye'nin sahip olduğu kültürel çeşitlilik, inanç turizmi için de büyük bir potansiyel yaratmaktadır. Türkiye; dağcllık turizmi, kış turizmi, termal turizm, golf turizmi, botanik turizmi, su altı dalış turiz$\mathrm{mi}$, mağara turizmi, gastronomi turizmi, helal turizm, ekoturizm ve kongre turizmi gibi turizm faaliyetleri için de çok uygun koşullara sahiptir (Öztürk 2010; GMKA 2011; Boğan vd. 2016).

Alternatif turizm türlerinin gelişimine yönelik yapılan yatırımlar deniz-güneş-kum üçlüsüne dayalı kitle turizminin yıkıcı etkilerinin azaltılması, turizmde bölgeler arası eşitsizliğin giderilmesi ve mevsimselliğin ortadan kaldırılmasına yönelik önemli adımlar niteliği taşımakla beraber, Türkiye'nin bu alanlardaki potansiyelinin tam anlamıyla değerlendirilemediği de gözükmektedir. Bu faaliyetler ancak isabetli politikalarla, tanıtım ve pazarlama stratejileriyle, girişimcilerin desteklenmesi ve önlerinin açılmasıyla canlandırılabilecek potansiyele sahiptir. Bu potansiyelin kullanılabilmesi, Türkiye'de turizmi, denizkum-güneş sıkışmışlı̆̆ından kurtarıp, turizmin yılın on iki ayına yayılmasını ve Türkiye'nin tüm bölgelerine dağılmasını sağlayacaktır. Bunun yanı sıra, Türkiye turizmi belirli turist pazarlarına (Almanya, Rusya vb.) ve belirli turizm aktivitelerine (deniz-kum-güneş, kültür turizmi vb.) bağımlı olmayacaktır. Türkiye, sahip olduğu turizm potansiyeli doğrultusunda çalışmalar yaparak turizm politika ve planlarını oluşturmalıdır. Böylece Türkiye, tüm dünyada önemli bir turist çekim merkezi haline gelecektir.

\section{ÇEKIM MODELI}

Adını, Newton'un kütle çekim kanunundan alan çekim modeli, iktisat alanyazınında da kendine yer bulmuş önemli modellerden biridir. Çekim modeli, iktisat alanyazınında ilk kez Tinbergen (1962) tarafından ülkeler arası mal ticareti ilişkilerini incelemek için kullanılmıştır. Çalışma sonucunda, ülkeler arası mesafenin artmasıyla birlikte taşıma ve kargo maliyetleri de artacağından yabancı malların talebinin azalacağı sonucuna ulaşılmıştır. Gelirin ise yabancı malların talebini arttıran ve mesafeye göre zit etkili bir faktör olduğu tespit edilmiştir. Böylece, Newton'un kütle çekim modelinde olduğu gibi iktisat biliminde de iki zıt etki bir olguyu açıklamak için kullanılmıştır.

Çekim modeli, benzer bir mantıkla turizm potansiyelini tespit edebilmek için de kurgulanmıştır. Ticaret, mal akışı ile ilgiliyken, turizm insanın hareketi ile ilgilidir. Bu nedenle, turizm ile ticaret arasındaki uluslararası akışların mekanizması ve modeli de farklı olacaktır. Bazı yazarlar, ülkeleri ekonomik bağlamda ölçmek için GSYH yerine ülkelerin nüfus büyüklüklerini analizlerinde kullanmıştır (Taplin ve Qiu 1997). Alanyazında iki ülke arasında karşıllklı turizm akışları için kurulan çekim modellerindeki tahmini parametrelerin yorumlanmasına yardımcı olan çok az teori mevcuttur (Morley vd. 2014). Genel olarak turizm bağlamında yer alan akademik çalışmalar, çekim modellemesinde bir dizi başlangıç noktası ve destinasyon arasındaki akışları analiz etmektedir. Bu analiz ancak bir zaman periyodu gibi kesitsel verilerle yapılabilmektedir. Birden fazla dönemin verileri içinse panel veri analiz teknikleri uygundur. Turizm ele alındığında, panel veri kaynakları olarak, turist gönderen ülke ve ev sahibi ülkenin GSYH'si, turist akımını artırıcı etkisi bakımından önemli parametrelerdir. Bununla beraber iki ülke arasındaki kültürel, tarihsel, etnik yakınlıklar ve uzaklık da önemli parametrelerdendir.

\section{ILGILI ÇALIŞMALAR}

Alanyazında çekim modeli ile turizm potansiyelini açıklamaya çalışan araştırmalar mevcuttur. Yavuz vd. (2014), 2008, 2009 ve 2010 yılı verileriyle Türkiye'yi ziyaret eden turist akımı üzerinde etkili olan faktörleri çekim modeli ile inceledikleri çalışmalarında, Türkiye'yi ziyaret eden turist akımı üzerinde etkili olan faktörlerin; turistlerin geldikleri ülkelerin Türkiye'ye olan uzaklığ 1 ve sahip oldukları nüfus potansiyelleri, turistlerin ortalama aylık gelir seviyeleri ve Türkiye ile kültürel, tarihi ve etnik bağlar olduğu görülmüştür. Çalışmada ayrıca, turizm akımının ülkelerin uzaklıklarından olumsuz olarak etkilendiği 
görülürken; ülke gelirlerinin ise turizm akımını olumlu olarak etkilediği tespit edilmiştir. Eita ve Jordaan (2007), Namibya'nın sahip olduğu turizm potansiyelini panel çekim modeli aracılığıyla tespit etmeyi amaçladıkları çalışmalarınin sonucunda, Namibya'ya gelen turist rakamları üzerinde komşuluk ilişkileri ve döviz kuru ile elektrik üretimindeki artışın olumlu etkide bulunduğu ancak, uzaklık faktörünün olumsuz bir etkiye sahip olduğu görülmüştür. Karagöz (2008), Türkiye turizminin geliştirilmesi amacıyla Türkiye'ye gelen turist rakamlarını etkileyen unsurları tespit etmeyi ve Türkiye' nin turizm potansiyelini belirlemeyi amaçladığ 1 çalışmasının sonucunda, Türkiye'ye gelen turist rakamlarını; ülkelerin ekonomik büyüklükleri, mesafe, kültürel, tarihi, etnik bağlar ve komşuluk ilişkileri gibi unsurların etkilediğini tespit etmiştir. Matias (2004), Portekiz'in turizm rakamlarını etkileyen unsurları araştırdı ni kullanmış ve GSYH ve ülkeler arası uzaklığın, Portekiz' in turist rakamlarını önemli ölçüde etkilediğini tespit etmiştir. Matias (2004) elde ettiği bu sonuç doğrultusunda Portekiz'i ziyaret eden ülkeler sıralamasında İspanya'nın ilk sırada yer almasının sebebini bu unsurla açıklamıştır.

\section{YÖNTEM}

\section{Araştırmanın Yöntemi}

Türkiye'nin diş turizm potansiyelini tespit etmeyi amaçlayan bu çalışmada, panel çekim modeli kullanılmıştır. Modele göre, iki ülke arasında gerçekleşen toplam diş ticaret hacmi, oran olarak ülkelerin sahip olduğu ekonomik büyüklük ile doğru, aralarındaki coğrafi uzaklık ile ise ters orantılıdır. Basit çekim modeli olarak da adlandırılan bu durum aşağıdaki formülle ifade edilebilmektedir:

$$
T_{i j}=A \frac{\left(Y_{i} Y_{j}\right)^{\alpha}}{D_{i j}^{\beta}}
$$

Bu formüle göre; $\mathrm{T}_{\mathrm{ij}}$, i ülkesi ile j ülkesi arasındaki ticareti; A, sabit katsayıyı; $Y_{i}$ ve $Y_{j}$ ihracatçı ve ithalatçı ülke GSYH'sini; $D_{i j}$, ihracatçı ile ithalatçı ülke arasındaki coğrafi uzaklığı temsil et- mektedir. GSYH'sinin; dış ticaret hacmini pozitif yönde; ülkeler arası coğrafi uzaklığı ise teoriyle uygun olarak negatif yönde etkilemesi beklenmektedir. Modelin doğrusallaştırılması amacıyla, denklemin her iki tarafının logaritması alınmaktadır:

$$
\log T_{i j}=A^{*}+\alpha \log \left(Y_{i} Y_{j}\right)-\beta \log D_{i j}+u_{i j}
$$

Yukarıdaki denklemde yer alan "A*," logaritması alınmış $\log \mathrm{A}^{\prime} \mathrm{y} 1, \alpha$ ve $\beta$ tahmini yapılacak parametreleri, " $\mathrm{U}_{\mathrm{ij}}$ ” ise ikili ticareti etkileyen rassal değişkenlerin etkilerini ifade etmektedir. Denklem, iki ülke arasında gerçekleşen ticaret hacminin, ülkelerin sahip olduğu büyüklüklerin artan fonksiyonu iken ülkelerin arasındaki mesafelerin ise azalan fonksiyonu olduğunu belirtmektedir.

\section{Araştırmanın Modeli}

Yöntem bölümünde tanıtılan basit çekim modelinin turist akımlarına uygulanmış biçimi aşağıda yer alan denklemdeki gibidir:

$$
\operatorname{TUR}_{i}=A\left[G_{i} / U_{i}\right]
$$

Yukarıdaki denklem, " $\mathrm{i}$ " ülkesinden gelen turist sayısının, turistlerin geldiği ülkenin büyüklüğ̈̈ ile doğru, aralarındaki uzaklık ile ise ters orantılı olduğunu ifade etmektedir. Denklem ayrıca, kendisine turist gelen ve turist gönderen ülkenin GSYH'sinin büyüklügüünün, gelen turist sayısını artırıcı etkide bulunduğunu belirtmektedir. Dolayısıyla denklem, kendisine turist gelen veya turist gönderen ülkelerin büyüklüklerinin sıfır değerine doğru ilerledikçe gelen turist sayısının da sıfıra ilerlediğini varsaymaktadır. Uzaklık değişkeninin ise gelen turist sayısına etkisinin azaltıcı veya artırıcı yönde de olabileceğini belirtmektedir. Uzaklıkla beraber, kültürel ve coğrafi farklılıkların artması sebebiyle, farklı destinasyonları ziyaret etme isteğinin turist sayısını artırabileceği veya bu durumun tam tersi yönde

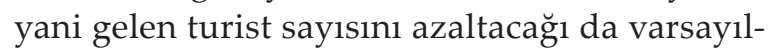
maktadır. Ayrıca, ülkeler arası mesafenin ulaşım maliyetlerini artırması sebebiyle seyahat maliyetleri de artacağından uzak ülkelerden gelen turist sayısı azalabilir. 


$$
\operatorname{TUR}_{i}=A\left(N_{i}\right)\left[G_{i} / U_{i}\right]
$$

Yukarıda yer alan ve uzun dönem dengesini ifade eden denkleme göre, denklem sonucunda uzun dönemde elde edilen tahmini gelen turist sayısı, ziyaretin gerçekleşmesi sonucundaki turist sayısına eşit olacaktır (TÛR=TUR). Bu durum, büyük nüfuslu ülkelerden gelen turist sayısının da daha fazla olabileceğini varsayarak, bu ve benzeri çalışmalarda ziyareti gerçekleştiren ülkelerin nüfuslarının da model içinde yer almasını sağlamaktadır. Bu nedenle, yukarıdaki denklemin logaritması alınıp doğrusallaştırılarak aşağıdaki tahmin edilebilir denkleme ulaşılmaktadır:

$$
\ln T U R_{i}=\beta_{0}+\beta_{1} \ln N_{i}+\beta_{2} \ln G_{i}-\beta_{3} \ln U_{i}+e_{i}
$$

Bu denklem ile gelen turist sayısı kişi başına GSYH ve iki ülkenin arasındaki mesafenin bir işlevi olarak belirtilmiş olacaktır.

\section{Araştırmanın Değişkenleri ve Verileri}

Araştırmanın analizde kullanılan değişkenler aşağıdaki gibidir:

$T U R_{i}: 2016$ yılında ülkeler itibariyle Türkiye'ye gelen turist sayıs1.

$K B G_{i}$ : Turist gönderen ülkenin 2016 yılında kişi başına düşen GSYH'si.

$G_{i}$ : Turist gönderen ülkenin 2016 yılı GSYH'si.

$U_{i}$ : Turist gönderen ülkenin başkentinin Türkiye'ye uzaklığı.

Türkiye'nin turist akımı üzerinde etkili olduğu düşünülen diğer birtakım unsurlar, bir dizi kukla değişken ile modelde yer almaktadır. Analizde yer alan kukla değişkenler ise aşağıda belirtilmiştir:

$K D_{1}$ : Türkiye ile kültürel, tarihsel ve/veya etnik yakınlık içinde olan ülkeler için 1, diğer ülkeler için 0 değerini alan kukla değişken.

$K D_{2}$ : Türkiye ile komşu olan ülkeler için 1, diğer ülkeler için 0 değerini alan kukla değişken.

$K D_{3}$ : Müslüman ülkeler için 1, diğer ülkeler için 0 değerini alan kukla değişken.

$K D_{4}$ : Avrupa ülkeleri için 1, diğer ülkeler için 0 değerini alan kukla değişken.
Çalışmada, TUR ${ }_{i}^{\prime}$ ye ait verilere Emniyet Genel Müdürlüğ̈ü aracılığıyla ulaşılırken, $G_{i}{ }^{\prime}$ ye ait verilere Dünya Bankası veritabanından, $U_{i}{ }^{\prime}$ ye ait verilere ise tr.distance.to sitesi aracılığıyla ulaşılmıştır. Çalışmada kullanılan ve logaritması alınarak oluşturulan genişletilmiş çekim modeli aşağıdaki biçimdedir:

$$
\begin{aligned}
\operatorname{lnTUR} R_{i}=\beta_{0}+ & \beta_{1} \ln N_{i}+\beta_{2} \ln G_{i}-\beta_{3} \ln U_{i}+\beta_{4} K 1 \\
& +\beta_{5} K 2+\beta_{6} K 3+e_{i}
\end{aligned}
$$

Çalışma kapsamında, 2016'da Türkiye'yi en az bir gece konaklama yapmak şartıyla ziyaret eden turistlere ait yatay kesit verilerinden yararlanılmıştır. Emniyet Genel Müdürlüğü'nden elde edilen verilere göre, 2016 'da, 103 farklı ülkeden toplamda 25 milyon 352 bin turist Türkiye'yi ziyaret etmiş̧ir.

\section{ANALIZ VE BULGULAR}

Genişletilmiş çekim modeline ait tahminler, Tablo 1'de verilmiştir. Tablo 1'e göre, Türkiye'yi ziyaret eden turist sayısının, geldikleri ülkenin ekonomik büyüklüğünden olumlu yönde, geldikleri ülkenin uzaklığından ise olumsuz yönde etkilendiği görülmektedir. Tabloda yer alan bir başka sonuca göre, turistlerin geldiği ülkenin Türkiye ile tarihsel, kültürel, etnik bağları ve ortak bir sınıra sahip olmasının turist rakamları üzerinde olumlu, ülkenin bir Müslüman ülkesi olmasının ise turist rakamları üzerinde olumsuz bir etkiye sahip olduğu görülmektedir. Bu sonuç, Müslüman ülkelerin genellikle düşük gelir düzeyine sahip olmalarıyla açılanabilir. Turistlerin geldiği ülkenin nüfus açısından büyük ve bir Avrupa ülkesi olmasının ise turist rakamları üzerinde olumlu veya olumsuz bir etkisinin bulunmadığ 1 görülmektedir. Çalışma için oluşturulan çekim modelinin, Türkiye'ye yönelik turist rakamlarındaki değişimi \%75 oranında açıladığı görülmektedir.

Çalışmada, çekim modeli tahminleri kullanılarak, Türkiye'nin ülkelere göre dış turizm potansiyeli sonuçlarına da ulaşılmıştır. Bu doğrultuda, çekim modelinin verdiği turist sayısı tahminleriyle turizm potansiyeli $(\mathrm{P})$, gerçek değer $(\mathrm{A})$ ifadeleri ile tanımlanmış ve bu değerlerin karşılaş- 
Tablo 1. Yerel Halkın Demografik Bilgileri

\begin{tabular}{|c|c|c|c|c|c|c|}
\hline \multirow[t]{2}{*}{ Değişkenler } & \multicolumn{6}{|c|}{ Katsayı Tahminleri } \\
\hline & $I$ & II & III & $I V$ & V & $V I$ \\
\hline Sabit & $19,520^{*}$ & $21,745^{*}$ & $18,447^{*}$ & $21,856^{*}$ & $18,978^{*}$ & $17,329^{*}$ \\
\hline $\ln N i$ & 0,001 & & & & & \\
\hline $\ln G i$ & $0,657^{*}$ & $0,744^{*}$ & $0,665^{*}$ & $0,614^{*}$ & $0,687^{*}$ & $0,691^{*}$ \\
\hline $\ln U I$ & $-1,627^{*}$ & $-1,579^{*}$ & $-1,478^{*}$ & $-1,783^{*}$ & $-1,529^{*}$ & $-1,322^{*}$ \\
\hline KD1 & & $1,225^{*}$ & & & & $1,601^{*}$ \\
\hline KD2 & & & $1,154^{*}$ & & & $1,206^{*}$ \\
\hline KD3 & & & & $-0,567^{* *}$ & & $-0,523^{* * *}$ \\
\hline KD4 & & & & & 0,361 & 0,398 \\
\hline$R 2$ & 0,501 & 0,697 & 0,576 & 0,594 & 0,544 & 0,601 \\
\hline$D-W$ & 1,357 & 1,498 & 1,037 & 1,264 & 1,289 & 1,412 \\
\hline$F-$ değgeri & 48,523 & 54,564 & 55,186 & 52,847 & 51,134 & 37,613 \\
\hline
\end{tabular}

Not: $\left({ }^{*}\right) /\left({ }^{* *}\right) /\left({ }^{* *}\right)$ işaretleri sırasıyla \%1 / \%5 / \%10 düzeylerindeki anlamlılı̆̆ belirtmektedir

tırmaları yapılarak turizm akımının hangi ülkeler için potansiyelinin altında, hangileri için üstünde ve hangileri için potansiyeline eşit olduğu saptanmıştır. Bu doğrultuda izlenen yaklaşım, P-A farkının 0'dan büyük olup olmamasına göre potansiyelin belirlenmesidir. Yapılan analiz sonucunda $\mathrm{P}-\mathrm{A}$ farkının pozitif olması ile turist rakamlarının sahip olunan potansiyelin altında, negatif olması ile ise potansiyelin üstünde olduğunu kabul etmektedir. Bu doğrultuda, analiz sonucunda elde edilen potansiyel akım değerleri Tablo 2'de görülmektedir. Sahip olduğu potansiyelin üzerinde turist gönderen ülkelerin listesi ise Tablo 3'te yer almaktadır.

\section{SONUÇ VE ÖNERILER}

Turizm sektörü, 20. yüzyılın ikinci yarısı itibari ile dünya ekonomisinde hızla gelişen sektörlerden biri haline gelmiştir. Türk turizmi için, turizmde harekete geçme dönemi olarak kabul edilen 1983 yılından günümüze kadar geçen sürede Türkiye turizminde, turist sayısı ve turizm gelirleri bakımından kayda değer gelişmeler sağlanmiştır (Aktaş 2011).

Buna rağmen 2014 yılında 34,3 milyar dolar olan turizm geliri, 2015 yılının Kasım ayında Rus jet uçağının düşürülmesinden sonra \%8,3 azalarak 31 milyar 464 milyon 777 bin dolara gerilemiştir (TUİK 2016). Benzer şekilde, İstanbul Sultanahmet'te 12 Ocak 2016'da gerçekleşen ve
Alman turist kafilesinin hedef alındığ saldırıdan sonra yılın ilk dört ayında bir önceki yıla oranla \%35,43'lük bir düşüş yaşayarak 2016

Tablo 2. P-A'ya Göre Genişleme Potansiyeline Sahip Ülkeler

\begin{tabular}{lclc}
\hline Ülke & $P-A$ & Ülke & $P-A$ \\
\hline BAE. & 2,991 & Nijerya & 1,002 \\
\hline Lübnan & 2,764 & Tayland & 0,988 \\
\hline Katar & 2,689 & Lüksemburg & 0,812 \\
\hline Kuveyt & 2,122 & Peru & 0,764 \\
\hline Sudan & 2,002 & Panama & 0,678 \\
\hline Yemen & 2,000 & Paraguay & 0,531 \\
\hline Umman & 1,984 & Yunanistan & 0,497 \\
\hline S. Arabistan & 1,932 & Ekvator & 0,301 \\
\hline Azerbaycan & 1,864 & Dominik & 0,216 \\
\hline Irak & 1,755 & Portekiz & 0,113 \\
\hline Ürdün & 1,721 & Bangladeş & 0,107 \\
\hline Cezayir & 1,699 & Venezuella & 0,101 \\
\hline Misir & 1,623 & Kenya & 0,100 \\
\hline Fas & 1,597 & İtalya & 0,098 \\
\hline İran & 1,491 & Macaristan & 0,093 \\
\hline Pakistan & 1,345 & Özbekistan & 0,052 \\
\hline Ukrayna & 1,221 & Slovenya & 0,049 \\
\hline KKTC. & 1,100 & Slovakya & 0,038 \\
\hline G. Afrika & 1,098 & Brezilya & 0,021 \\
\hline Hindistan & 1,032 & Meksika & 0,012 \\
\hline Gürcistan & 1,026 & Hirvatistan & 0,004 \\
\hline Ermenistan & 1,005 & & \\
\hline & & & \\
\hline
\end{tabular}


yılında 10 milyon turist kaybedilmiştir (Ege Turistik İşletmeler ve Konaklamalar Birliği 2017).

Bu kaybın ardından Türkiye, dünyanın en büyük turizm destinasyonları arasında dokuz basamak birden gerilemiştir (Turizm Data Bank 2017). Öte yandan, Türkiye'ye yönelik gerçekleştirilen 15 Temmuz 2016'daki darbe girişimi ve Türkiye'nin de içinde bulunduğu Orta Doğu ülkelerinde yaşanan bölgesel istikrarsızlıklar, te-

Tablo 3. P-A'ya Göre Potansiyelinin Üzerinde Turist Gönderen Ülkeler

\begin{tabular}{|c|c|c|c|}
\hline Ülke & $P-A$ & Ülke & $P-A$ \\
\hline Almanya & $-0,084$ & Türkmenistan & $-1,339$ \\
\hline Hollanda & $-0,093$ & G. Kore & $-1,345$ \\
\hline Japonya & $-0,102$ & İsveç & $-1,366$ \\
\hline İrlanda & $-0,197$ & Kanada & $-1,402$ \\
\hline Kazakistan & $-0,201$ & İngiltere & $-1,439$ \\
\hline İspanya & $-0,267$ & Filipinler & $-1,498$ \\
\hline Tunus & $-0,304$ & Romanya & $-1,516$ \\
\hline Libya & $-0,383$ & Arnavutluk & $-1,530$ \\
\hline İsrail & $-0,411$ & Suriye & $-1,551$ \\
\hline Bahreyn & $-0,475$ & Afganistan & $-1,593$ \\
\hline Endonezya & $-0,529$ & Bulgaristan & $-1,627$ \\
\hline Singapur & $-0,594$ & Litvanya & $-1,684$ \\
\hline Şili & $-0,622$ & Brezilya & $-1,692$ \\
\hline Uruguay & $-0,684$ & Kolombiya & $-1,701$ \\
\hline Fransa & $-0,741$ & Okyanusya & $-1,726$ \\
\hline Finlandiya & $-0,786$ & Senegal & $-1,763$ \\
\hline Arjantin & $-0,858$ & Moldova Cum. & $-1,785$ \\
\hline Çin & $-0,883$ & Rusya Fed. & $-1,864$ \\
\hline Estonya & $-0,944$ & Avustralya & $-1,887$ \\
\hline Malezya & $-0,981$ & Sirbistan & $-1,896$ \\
\hline Avusturya & $-1,054$ & Kosova & $-1,904$ \\
\hline Belçika & $-1,078$ & Kirgizistan & $-1,945$ \\
\hline Danimarka & $-1,104$ & Yeni Zelanda & $-1,978$ \\
\hline İsviçre & $-1,158$ & Malta & $-1,982$ \\
\hline İzlanda & $-1,167$ & Letonya & $-1,994$ \\
\hline Çek Cumhuriyeti & $-1,203$ & Bosna Hersek & $-1,996$ \\
\hline Polonya & $-1,264$ & Makedonya & $-1,998$ \\
\hline Norveç & $-1,297$ & Tacikistan & $-2,011$ \\
\hline ABD & $-1,301$ & G. Kıbrıs Rum Y. & $-2,014$ \\
\hline B. Rusya & $-1,326$ & Karadağ & $-2,109$ \\
\hline
\end{tabular}

rör olayları ve bu olaylar doğrultusunda ortaya çıkan güvenlik açı̆̆ı da Türkiye'nin son iki yıl içindeki dış turizm potansiyelini rakamsal olarak bir hayli geriletmiştir. Özellikle Almanya, Rusya gibi belirli ülke pazarlarının ziyaret ettiği ve deniz-kum-güneş gibi belirli turizm aktivitelerinin gerçekleştirildiği Türkiye gibi ülkeler için bu durum, belirli pazarlara bağlı olması sebebiyle bu ve benzeri durumlardan daha çok etkilenmektedir.

Oysa Türkiye, kültür turizminden sağlık turizmine, gastronomi turizminden ekoturizme kadar geniş yelpazede ürün ve hizmet sunumunu içerecek potansiyele sahip bir ülkedir. Türkiye' nin bu potansiyeli değerlendirmesi, hem turizmin mevsimsellik sorununu en aza indirgeyecek hem de turizm çeşitliliği sebebiyle farklı ülke pazarlarına da hitap ederek diğer ülkelerle önemli bir rekabet avantajına sahip olacaktır. Bu nedenle, Türkiye turizminin mevcut yapısının analiz edilerek gelen turist rakamı üzerinde etkili olan unsurların tespiti ve turist akımı bağlamında potansiyelin altında kalan ülkelerin saptanarak hedefe yönelik tanıtım ve teşvik politikalarının geliştirilmesi, Türkiye turizmi açısından önem arz etmektedir.

Türkiye' nin turist akımı üzerinde etkili olan unsurları ve Türkiye'nin dış turizm potansiyelini çekim modeli aracılı̆̆ıyla belirlemeye çalışılan bu çalışmadan elde edilen sonuçlar doğrultusunda, Türkiye'yi ziyaret eden ve en az bir gece konaklama yapan turist sayısının, geldikleri ülkenin ekonomik büyüklüğü unsuru yönüyle olumlu, ülkenin uzaklığı unsuru yönünden ise olumsuz yönde etkilendiği tespit edilirken, geldikleri ülkenin nüfus açısından büyük olması unsurunun ise turist akımı üzerinde bir etkisinin bulunmadığı saptanmıştır. Ayrıca, turistlerin geldiği ülkenin Türkiye ile birtakım bağlarının (tarihsel, kültürel, etnik) veya ortak sinıra sahip olma unsurunun turist rakamları üzerinde artır1Cı, ülkenin bir Müslüman ülkesi olması unsurunun ise gelen turist rakamlarını azaltıcı bir etkide bulunduğu görülmüştür. Bu sonuç, Müslüman ülkelerin çoğunlukla düşük gelir seviyesinde yer almaları, büyük çoğunluğunun Türkiye'de çok fazla gelişme göstermemiş helal turizmi konsept- 
li otelleri tercih etmeleri ve genellikle inanç turizmi aktivitelerine katılmalarıly yorumlanabilir. Turistlerin geldiği ülkenin bir Avrupa ülkesi olması unsurunun ise turist rakamları üzerinde bir etkisinin olmadığ 1 görülmüştür. Çalışmadan elde edilen bir başka sonuca göre, Türkiye'ye yönelik turist akımı, sahip olduğu potansiyel bakımından değerlendirildiğinde, Türkiye'ye gelen ve en az bir gece konaklama yapan ülkelerin yarısından fazlasının potansiyelini aşan rakamlarda turist gönderdiği saptanmıştır. Ülkeler, daha fazla turist gönderme potansiyelleri bakımından incelendiğinde ilk beşte (Tablo 2) BAE, Lübnan, Katar, Kuveyt ve Sudan'ın yer aldığı görülmektedir. Potansiyelinin üzerinde turist akımına sahip ülkeler tablosu (Tablo 3) incelendiğinde ise; Almanya, Hollanda, Japonya, İrlanda ve Kazakistan'ın ilk beş ülke arasında yer aldığı görülmektedir.

Çalışma bulguları ışığında, sahip olduğu turist potansiyelinden daha az turist gönderen ülkelerin çoğunlukla orta ve alt gelir grubunda yer alan ülkeler olması sebebiyle, turizmde pazar çeşitliliğini de artırmak amacıyla, bu ülkelerin turizm analizlerinin iyi yapılması, uygun pazarlama ve tanıtım politikalarının izlenmesi ve bu ülkelere yönelik uygun turizm politikalarının benimsenmesi önem arz etmektedir. Buna ek olarak, Türkiye ile tarihsel, kültürel ve etnik bağlara sahip devletlerle gerek ikili ticari gerekse diplomatik ve dostane ilişkilerin geliştirilmesi de turist akımının artışını sağlayacaktır. Son olarak, potansiyelinin altında turist gönderen ülkeler için Türkiye özelinde tanıtım ve pazarlama faaliyetlerinin gerçekleştirilmesi ve mevcut çalışmaların artırılması da yerinde olacaktır. Çalışma bulguları, Türkiye'yi belirli ülkelerin ziyaret ettiği ve belirli turizm aktivitelerinin gerçekleştirildiği ülke imajından kurtarabilmesi, Türkiye'nin turist akımını etkileyen faktörleri belirlemesi ve bu doğrultuda da Türkiye'nin dış turizm potansiyelini tespiti açısından önemlidir. Ayrıca, alanyazın taraması sürecinde, panel çekim modeli ile yapılan çalışmaların daha çok dış ticaret alanında yapıldığı görülmüştür. Turizm alanında panel çekim modeli ile ortaya konan bu çalışma ile alanyazına da katkıda bulunulacağı düşünülmektedir.
Bu çalışmada, Türkiye'nin dış turizm potansiyelini tespit etmek ve bu potansiyeli mevcut turizm pazarları dışındaki farklı pazarlar için de geliştirmek amaçlanmıştır. Bu bağlamda, çalışma kapsamında birtakım değişkenler kullanılmıştır. Konuya ilişkin olarak gelecekte yapılabilecek çalışmalarda, Türkiye'nin dış turizm potansiyelinin farklı değişkenler ile olan ilişkilerinin ve bu ilişkilerin turizm sektörü dışındaki çeşitli sektörlere katkılarının, farklı analiz yöntemleri kullanılarak incelenmesinin de yararlı olacağ 1 düşünülmektedir.

\section{KAYNAKÇA}

Aktaş, C. (2011). Türkiye'nin Turizm Gelirini Etkileyen Değişkenler İçin En Uygun Regresyon Denkleminin Belirlenmesi, Doğuş Üniversitesi Dergisi, 6 (2): 163-174.

Bahar, O. (2006). Turizm Sektörünün Türkiye'nin Ekonomik Büyümesi Üzerindeki Etkisi: VAR Analizi Yaklaşımı, Yönetim ve Ekonomi: Celal Bayar Üniversitesi İktisadi ve İdari Bilimler Fakültesi Dergisi, 13 (2): 137-150.

Balaguer, J. ve Cantavella-Jordá, M. (2002). Tourism as a Long-Run Economic Growth Factor: The Spanish Case, Applied Economics, 34 (7): 877-884.

Boğan, E., Batman, O. ve Sarışık, M. (2016). Helal Turizmin Kavramsal Çerçevesi ve Türkiye'deki Uygulamalar Üzerine Bir Değerlendirme, 3rd International Congress of Tourism \& Management Researches, Antalya, 20-22 May1s 2016.

Coşan, B. (2016). Nisan'da Türkiye'ye Gelen Turist Sayısında 17 Yılın En Büyük Düşüş Yaşand1, http://wwww.hurriyet. com.tr/nisanda-turkiyeye-gelen-turist-sayisinda-17-yilinen-buyuk-dusus-yasandi-40109992, Erişim Tarihi: $25 \mathrm{Ka}-$ sim 2016.

Çardak, M. (2016). Turizm Haftası ve Terör!, http://www.kirikhanolay.com.tr/yazarlar/mehmet-cardak/turkiye-de-terorortadogu-da-savas/374/, Erişim Tarihi: 25 Kasim 2016.

GMKA. (2011). Çanakkale Turizm Çalıştayı Raporu, http:// docplayer.biz.tr/1640034-Canakkale-turizm-calistayiraporu.html, Erişim Tarihi: 25 Kasım 2016.

Çetin, T. ve Gürgil, F. (2014). Üniversite Öğrencilerinin Bartın'ın Doğal ve Kültürel Turizm Değerlerine Yönelik Farkındalıkları, Uşak Üniversitesi Sosyal Bilimler Dergisi, 7 (4): 255-274.

Dalman, A. (2016). Türkiye'nin Turistik Değerleri, http://docplayer.biz.tr/19218695-T-c-kumluca-haciveldler-dlkogretdmokulu-portakal-cdcegd-gazetesd.html, Erişim Tarihi: $25 \mathrm{Ka}$ sim 2016.

Ege Turistik İşletmeler ve Konaklamalar Birliği. (2017). İşler: Turizm Sektörü Ağır Yaralı, http://wwww.hurriyet.com.tr/ isler-turizm-sektoru-agir-yarali-40327188, Erişim Tarihi: 12 Mart 2017.

Eita, J.H. ve Jordaan, A. C. (2007). Estimating the Tourism Poten $\neg$ tial in Namibia. MPRA, https://mpra.ub.unimuenchen.de/5788/, Erişim Tarihi: 15 Nisan 2017. 
Göğebakan, Y. (2015). Dünya Üzerindeki Kültürel Varlıkların Turizme ve Ekonomiye Katkısı, Anadolu Üniversitesi Sanat ve Tasarm Dergisi, 5 (9): 48-71.

Gündüz, L. ve Hatemi-J, A. (2005). Is the Tourism-Led Growth Hypothesis Valid for Turkey?, Applied Economics Letters, 12 (8): 499-504.

Jiménez I. C. ve Ortuño, M. A. (2005). The Role of the Tourism Sector in Economic Development: Lessons from the Spanish Experience, 45th Congress of the European Regional Science Association, 23-27 Ağustos 2005, Amsterdam, Hollanda.

Karagöz, K. (2008). Türkiye'nin Turizm Potansiyeli: Çekim Modeli Yaklaşımı. Anatolia: Turizm Araștırmaları Dergisi, 19 (2): 149-156.

Katırcioğlu, S. (2009). Trade, Tourism and Growth: The Case of Cyprus, Applied Economics, 41 (21): 2741-50.

Katırcioğlu, S. (2010). International Tourism, Higher Education, and Economic Growth: the Case of North Cyprus, The World Economy, 33 (12): 1955-1972.

Kaynar, M. N. (2009). Turizm Anlayışı Değişmeli, http://wwww. besam.org.tr/yazarlarimiz/mehmet-nuri-kaynar/turizmanlay $\%$ C4\%B1\%C5\%9F\%C4\%B1, Erişim Tarihi: $25 \mathrm{Ka}-$ sim 2016.

Kırbaş, S. ve Kasman, A. (2004). Turizm Gelirleri ve Ekonomik Büyüme Arasındaki Eşbütünleşme ve Nedensellik İlişkisi, İktisat İşletme ve Finans Dergisi, 220: 122-131.

Kızılgöl, A. G. Ö. ve Erbaykal, E. (2008). Türkiye'de Turizm Gelirleri ile Ekonomik Büyüme İlişkisi: Bir Nedensellik Analizi, Süleyman Demirel Üniversitesi İktisadi ve İdari Bilimler Fakültesi Dergisi, 13 (2): 351-360.

Matias, A. (2004). Economic Geography, Gravity and Tourism Trade: The Case of Portugal, 1st. Congress on Tourism Economics, Palma, 28-29 Mayis 2004.

Morley, C., Rosselló, J. ve Santana-Gallego, M. (2014). Gravity Models for Tourism Demand: Theory and Use, Annals of Tourism Research, 48: 1-10.

Nayır, M. (2016). Turizm Sektöründe Neler Oluyor?, http:// www.sgk.com.tr/344-Makale1-turizm-sektorunde-neleroluyor.html, Erişim Tarihi: 25 Kasım 2016.

Özcan, C. C. (2015). Turizm Gelirleri-Ekonomik Büyüme İlişkisinin Simetrik ve Asimetrik Nedensellik Yaklaşımı ile Analizi: Türkiye Örneği, Erciyes Üniversitesi İktisadi ve İdari Bilimler Fakültesi Dergisi, 46: 177-199.

Özer, E. Y. (2015). Turizm Sektöründeki Teşviklerin TMS-20 Çerçevesinde Muhasebeleştirilmesi ve Mardin İline Yönelik Bir Araştırma (Yayınlanmamış Yüksek Lisans Te- zi). Balıkesir: Balıkesir Üniversitesi Sosyal Bilimler Enstitüsü.

Öztürk, A. T. (2010). Turizm Endüstrisi ve İşletmelerinde Paradigma Değişimi ve Sezgisel Kararların Önemi, I. Disiplinlerarası Turizm Araștırmaları Kongresi, Nevșehir, 27-30 Mayis 2010.

Pırnar, İ. (2013). Uluslararası Turizm İşletmeciliğgi. Ankara: Nobel Akademik Yayıncilik.

Şit, M. (2016). Türkiye'de Turizm Sektörünün İstihdama Katkıs1, Akademik Yaklaşımlar Dergisi, 7 (1): 109.

Taplin, J. ve Qiu, M. (1997). Car Trip Attraction and Route Choice in Australia. Annals of Tourism Research, 24: 624-637.

Tinbergen, J. (1962). An Analysis of World Trade Flows. New York: The Twentieth Century Fund.

TUIK. (2016). Türkiye'nin 2016 Turizm Gelirlerinde Büyük Gerileme, http://haberrus.com/economics/2017/01/31/ turkiyenin-2016-turizm-gelirlerinde-buyuk-gerileme.html, Erişim Tarihi: 22 Nisan 2017.

Turizm Data Bank. (2017). 2016 Krizi Yeni Otel Yatırımlarını Frenledi, http://www.turizmdatabank.com/haber/2016krizi-yeni-otel-yatirimlarini-frenledi, Erişim Tarihi: 20 Mart 2017.

TURSAB. (2016). Turizmin Ekonomideki Yeri, http://www.tursab.org.tr/tr/turizm-verileri/istatistikler/turizmin-ekonomideki-yeri/gsmh-icindeki-payi-1963-_79.html, Erişim Tarihi: 22 Kasım 2016

UNWTO. (2015). UNWTO Annual Report 2015, http://cf.cdn. unwto.org/sites/all/files/pdf/annual_report_2015_lr.pdf, Erişim Tarihi: 24 Mayıs 2017.

UNWTO. (2016). Tourism Highligts 2016 Edition, http://www. dadosefatos.turismo.gov.br/images/pdflestatisticas_indicadores/UNTWO_Tourism_Highlights_2016_Edition.pdf, Erişim Tarihi: 24 Mayıs 2017.

Usta, Ö. (1995). Turizm. İstanbul: Altın Kitaplar Yayınevi.

Yavuz, S., Kabadayı, B., Savaş, N. ve Doker, A. C. (2014). Türkiye Turizm Talebi: Bir Çekim Modeli Uygulaması, AIBÜ-İBF Ekonomik ve Sosyal Araştırmalar Dergisi, 10 (10): 133-141.

Yıldırım, J. ve Öcal, N. (2004). Tourism and Economic Growth in Turkey, Ekonomik Yaklaşım, 15 (52-53): 131-141.

Yüksel, İ. (2013). Turizmde Mekansal Altyapının Karşılanmasinda Yerel Firsatların Değerlendirilmesi, Sosyal ve Beşeri Bilimler Dergisi, 5 (2): 179-191. 


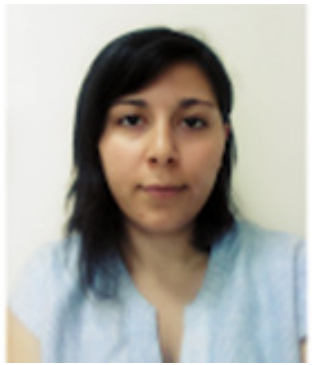

\section{Buket BULUK}

Muğla Sıtkı Koçman Üniversitesi Turizm İşletmeciliği ve Otelcilik Meslek Yüksekokulu'ndan mezun oldu (2009). Burada aldığı iki yıllık eğitimini, Dikey Geçiş Sınavı ile Akdeniz Üniversitesi Alanya İşletme Fakültesi Turizm İşletmeciliği Bölümünde fakülte ve bölüm ikincisi olarak tamamladı (2013). 2014 yılında ÖYP ile Çanakkale Onsekiz Mart Üniversitesi Turizm Fakültesi'nde Araştırma Görevlisi olarak göreve başladı. Yüksek lisans derecesini Çanakkale Onsekiz Mart Üniversitesi Sosyal Bilimler Enstitüsü Turizm İşletmeciliği Anabilim dalından (2016) aldı. Halihazırda Çanakkale Onsekiz Mart Üniversitesi Sosyal Bilimler Enstitüsü Turizm İşletmeciliği Anabilim dalında doktora eğitimine devam etmektedir. Halen Çanakkale Onsekiz Mart Üniversitesi Turizm Fakültesi Turizm İşletmeciliği bölümünde görev yapmaktadır. Temel çalışma alanları Turizm Pazarlaması, Seyahat Acentacılığı, E-Turizm'dir.

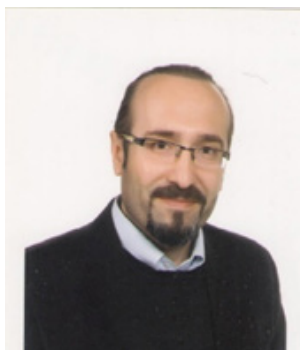

\section{Erol DURAN}

Çanakkale Onsekiz Mart Üniversitesi Turizm İşletmeciliği Otelcilik Yüksekokulu Konaklama İşletmeciliği bölümünden mezun oldu (2001). Yüksek lisans derecesini Çanakkale Onsekiz Mart Üniversitesi Sosyal Bilimler Enstitüsü Turizm İşletmeciliği Anabilim dalından (2003) aldı. Doktora derecesini ise Dokuz Eylül Üniversitesi Sosyal Bilimler Enstitüsü Turizm İşletmeciliği Anabilim dalından (2010) aldı. 2002 yılında Çanakkale Onsekiz Mart Üniversitesi'nde Araştırma Görevlisi olarak çalışmaya başladı. Doçentlik unvanını turizm alanında aldı (2016). Halen Çanakkale Onsekiz Mart Üniversitesi Turizm Fakültesi Turizm İşletmeciliği bölümünde görev yapmaktadır. Temel çalışma alanları Sürdürülebilir Turizm, Kültür ve Turizm Sosyolojisi'dir. 